\title{
HUBUNGAN KONTRASEPSI SUNTIK DENGAN PENINGKATAN BERAT BADAN AKSEPTOR \\ (Studi Di BPS Dwenti K.R. Desa Sumberejo Kabupaten Lamongan 2015)
}

\author{
Ida Susila* \\ Triana Riski Oktaviani** \\ *Dosen Program Studi D III Kebidanan Universitas Islam Lamongan \\ **Mahasiswa Program Studi D III Kebidanan Universitas Islam Lamongan
}

\begin{abstract}
ABSTRAK
Kontrasepsi suntik adalah obat pencegah kehamilan yang pemakaiannya dilakukan dengan jalan menyuntikan obat tersebut pada wanita subur. Adapun tujuan dalam penelitian ini adalah mengidentifikasi KB suntik, mengidentifikasi Berat badan pada akseptor KB suntik, dengan tujuan menganalisis hubungan kontrasepsi suntik dengan peningkatan berat badan akseptor.

Desain penelitian yaitu analitik observasional dengan pendekatan case control. Populasi dalam penelitian ini adalah seluruh akseptor KB suntik di BPS Dwenti Krudia. Variable dalam penelitian ini adalah hubungan kontrasepsi suntik dengan peningkatan berat badan akseptor. Tehnik pengambilan sampel dengan probability sampling dengan tehnik simpel random sampling.Sampel sebanyak 28 responden.

Dari hasil penelitian bahwa sebagian besar akseptor $\mathrm{KB}$ suntik mengalami peningkatan berat badan. Data yang diperoleh dianalisa analitik menggunakan uji koefisien phi menggunakan SPSS. Hasil penelitian ini menunjukkan bahwa pemakaian KB suntik dengan peningkatan berat badan. Dari hasil uji koefisien phi dengan SPSS didapatkan nilai $\mathrm{r} \varnothing=0,372 \mathrm{~T}$ hitung $(3,877)$. Dan p: 0,049 dimana <0,05 dengan demikian dapat disimpulkan bahwa terdapat hubungan kontrasepsi suntik dengan peningkatan berat badan akseptor.

Dengan penelitian ini diharapkan bisa bermanfaat dan menjadi masukan bagi lahan praktek dalam memberikan pelayanan KB suntik dan mengobservasi berat badan akseptor setiap kali kunjungan.
\end{abstract}

Kata kunci: Peningkatan Berat Badan, Aseptor KB Suntik

\section{PENDAHULUAN}

Kontrasepsi suntik adalah obat pencegah kehamilan yang pemakaiannya dilakukan dengan jalan menyuntikan obat tersebut pada wanita subur. Pemakaian kontrasepsi suntik baik kontrasepsi suntik bulanan maupun tribulanan mempunyai efek samping utama yaitu peningkatan berat badan, gangguan haid, sakit kepala, keputihan dan pada sistem kardiovaskuler. Faktor yang mempengaruhi perubahan berat badan akseptor $\mathrm{KB}$ suntik adalah adanya hormon progesteron yang 
kuat sehingga merangsang hormon nafsu makan yang ada di hipotalamus. Dengan adanya nafsu makan yang lebih banyak dari biasanya tubuh akan kelebihan zatzat gizi. Kelebihan zat-zat gizi oleh hormon progesteron dirubah menjadi lemak dan disimpan di bawah kulit. Perubahan berat badan ini akibat adanya penumpukan lemak yang berlebih hasil sintesa dari karbohidrat menjadi lemak (Mansjoer, 2003).

Berat badan merupakan ukuran antropometri yang terpenting yang digunakan sebagai ukuran laju pertumbuhan fisik, disamping itu berat badan digunakan sebagai ukuran perhitungan dosis obat dan makanan. Berat badan menggambarkan jumlah dari protein, lemak, air, dan mineral pada tulang. Efek samping utama pemakaian Depo Medroxy Progesterone Acetate adalah kenaikan berat badan. Sebuah penelitian melaporkan peningkatan berat badan lebih dari 2,3 kilogram pada tahun pertama dan selanjutnya meningkat secara bertahap hingga mencapai 7,5 kilogram selama enam tahun. Sedangkan pemakaian cyclofem berat badan meningkat ratarata dua hingga tiga kilogram tahun pertama pemakaian, dan terus bertambah selama tahun kedua. (Varney, 2007:483, 484).

Berdasarkan laporan BPS Ny. Dwenti krudia R, Amd. Keb. Desa Sumberejo Lamongan. Dengan data sekunder didapatkan pada bulan januari sampai maret 2015 terdapat 122 pasangan usia subur. Adapun pasangan yang menggunakan kontrasepsi suntik sebesar 65 akseptor, yang mengalami peningkatan berat badan yaitu 25 akseptor $(38,5 \%)$. Banyak akseptor
KB suntik yang mengalami peningkatan berat badan.

Wanita yang menggunakan kontrasepsi Depot medroxy progesterone acetate (DMPA) atau dikenal dengan KB suntik tiga bulan, rata-rata mengalami peningkatan berat badan sebanyak 11 pon atau 5,5 kilogram dan mengalami peningkatan lemak tubuh sebanyak $3,4 \%$ dalam waktu tiga tahun pemakaian, berdasarkan penelitian yang dilakukan oleh University of Texas Medical Branch (UTMB) (Mansjoer, 2003:354). Sedangkan pada kontrasepsi suntik bulanan efek samping terhadap berat badan sangatlah ringan, umumnya pertambahan berat badan sedikit (Hartanto, 2003:158).

Menurut data dari DINKES kabupaten Lamongan pada bulan Januari sampai Maret tahun 2015, peserta KB aktif sebesar 225,268 $(122,41 \%)$ dari 283,642 pasangan usia subur di Lamongan. Adapun jenis kontrasepsi yang dipakai yaitu kontrasepsi suntik sebesar 118,498 $(116,51 \%)$ dan kontrasepsi lain sebesar 611,265 (215,50\%) dari 283,642 pasangan usia subur di Lamongan.

Berdasarkan hasil laporan bulan Januari sampai Desember 2014 jumlah akseptor KB di wilayah Puskesmas Lamongan didapatkan KB suntik sebanyak 5699 dari 13163 pasangan usia subur. Beberapa keluhan akseptor $\mathrm{KB}$ suntik di wilayah puskesmas Lamongan adalah amenorhoe 20 orang ( $0,35 \%$ ), peningkatan berat badan 60 orang $(1,05 \%)$, spotting 15 orang $(0,26 \%)$, pencapaian kasus tertinggi pada peningkatan berat badan sebesar 60 orang $(1,05 \%)$. 
Upaya mengatasi agar tidak terjadi peningkatan berat badan yaitu petugas kesehatan melakukan observasi berat badan setiap kali kunjungan atau melakukan penimbangan berat badan. Untuk memperkecil resiko pemakaian kontrasepsi suntik terhadap peningkatan berat badan perlu diadakannya penyuluhan yang menyeluruh kepada seluruh akseptor $\mathrm{KB}$ suntik dan menganjurkan untuk melakukan diet rendah kalori, mengurangi konsumsi lemak, lebih banyak mengkonsumsi protein, banyak mengkonsumsi serat makanan dan olahraga yang proporsional untuk menjaga berat badannya.

\section{PEMBAHASAN}

Data Umum

\section{Usia}

Tabel 5.1 Distribusi frekwensi Responden berdasarkan usia di BPS.Dwenti Krudia, Amd. Keb. Di Desa Sumberejo Kecamatan Lamongan Kabupaten Lamongan tahun 2015.

\begin{tabular}{|l|l|c|c|}
\hline No & \multicolumn{1}{|c|}{ Umur } & Frekwensi & $\begin{array}{c}\text { Prosentase } \\
(\%)\end{array}$ \\
\hline 1. & $<\quad 20$ & 1 & 3,6 \\
2. & tahun & 20 & 71,4 \\
3. & $20-35$ & 7 & 25 \\
& tahun & 28 & 100 \\
& $36-45$ & & \\
& tahun & & \\
& Jumlah & & \\
\hline
\end{tabular}

Sumber: kartu $K B$

Dari Tabel diatas didapatkan data bahwa sebagian besar responden berusia 20-35 tahun yakni 20 responden $(71,4 \%)$ dan sebagian kecil responden berusia $<20$ tahun yakni 1 responden $(3,6 \%)$.
2. Pekerjaan

Tabel 5.2 Distribusi frekwensi Responden berdasarkan pekerjaan di BPS.Dwenti Krudia, Amd. Keb. Di Desa Sumberejo Kecamatan Lamongan Kabupaten Lamongan tahun 2015.

\begin{tabular}{|c|c|c|}
\hline Pekerjaan & $\begin{array}{c}\text { Frekue } \\
\text { nsi }\end{array}$ & $\begin{array}{c}\text { Prosentase } \\
(\%)\end{array}$ \\
\hline Bekerja & 10 & 35,7 \\
Tidak & 18 & 64,3 \\
bekerja & 28 & 100 \\
Jumlah & \\
\hline
\end{tabular}

Sumber: kartu $K B$

Dari tabel 5.2 dapat diketahui bahwa sebagian besar responden di BPS.Dwenti Krudia, Amd. Keb. Di Desa Sumberejo Kecamatan Lamongan Kabupaten Lamongan akseptor KB suntik tidak bekerja sebanyak 18 akseptor dari 28 akseptor KB suntik $(64,3 \%)$.

\section{Pendidikan}

Tabel 5.3 Distribusi frekwensi Responden berdasarkan pendidikan di BPS.Dwenti Krudia, Amd. Keb. Di Desa Sumberejo Kecamatan Lamongan Kabupaten Lamongan tahun 2015.

\begin{tabular}{|c|c|c|}
\hline $\begin{array}{c}\text { Pendidika } \\
\mathrm{n}\end{array}$ & $\begin{array}{c}\text { Frekwe } \\
\text { nsi }\end{array}$ & $\begin{array}{c}\text { Prosentase } \\
(\%)\end{array}$ \\
\hline SD & 0 & 0 \\
SMP & 7 & 25 \\
SMA & 15 & 53,6 \\
PT & 6 & 21,4 \\
Jumlah & 28 & 100 \\
\hline
\end{tabular}

Sumber: kartu $K B$

Dari tabel 5.3 dapat diketahui bahwa responden di BPS Dwenti Krudia,Amd.Keb. Sumberejo Lamongan akseptor KB suntik sebagian besar pendidikan terakhirnya SMA sebanyak 15 akseptor dari 28 akseptor KB suntik $(53,6 \%)$ dan sebagian kecil pendidikan terakhirnya PT sebanyak 
6 akseptor dari 28 akseptor KB suntik $(21,4 \%)$.

\section{Data Khusus}

Data yang terkumpul sejumlah 28 responden, dengan karakteristik responden meliputi jenis KB suntik dan peningkatan berat badan.

Untuk pemaparan dapat dilihat dalam tabel di bawah ini:

Jenis kontrasepsi suntik

Tabel Distribusi frekuensi responden berdasarkan akseptor KB suntik di BPS Dwenti Krudia. Sumberejo Kecamatan Lamongan Kabupaten Lamongan tahun 2015.

\begin{tabular}{|c|c|c|c|}
\hline No & $\begin{array}{c}\text { Kontrasepsi } \\
\text { suntik }\end{array}$ & $\begin{array}{c}\text { Freku } \\
\text { ensi }\end{array}$ & $\begin{array}{c}\text { Prosentase } \\
(\%)\end{array}$ \\
\hline 1 & Suntik 1 bulan & 10 & 35,7 \\
2 & Suntik 3 bulan & 18 & 64,3 \\
& Jumlah & 28 & 100 \\
\hline
\end{tabular}

Sumber: kartu $K B$

Dari tabel 5.4 dapat diketahui bahwa sebagian besar responden di BPS Dwenti Krudia. Sumberejo kecamatan Lamongan kabupaten Lamongan adalah akseptor KB suntik 3 bulan sebanyak 18 akseptor dari 28 akseptor KB suntik $(64,3 \%)$.

\section{Peningkatan berat badan}

Tabel 5.5 Distribusi frekuensi responden berdasarkan peningkatan berat badan di BPS Dwenti Krudia. Sumberejo Kecamatan Lamongan Kabupaten Lamongan tahun 2015.

\begin{tabular}{|c|c|c|c|}
\hline No & $\begin{array}{c}\text { Peningkatan } \\
\text { berat badan }\end{array}$ & Frekuensi & $\begin{array}{c}\text { Prosentase } \\
(\%)\end{array}$ \\
\hline 1 & Naik & 26 & 92,9 \\
2 & Tidak naik & 2 & 7,1 \\
& Jumlah & 28 & 100 \\
\hline
\end{tabular}

Sumber: kartu $K B$

Dari tabel 5.5 dapat diketahui bahwa sebagian besar responden di BPS Dwenti Krudia. Sumberejo Kecamatan Lamongan Kabupaten Lamongan. Akseptor KB suntik mengalami peningkatan berat badan sebanyak 26 akseptor dari 28 akseptor KB suntik (92,9\%) dan sebagian kecil tidak mengalami peningkatan berat badan sebanyak 2 akseptor dari 28 akseptor KB suntik $(7,1 \%)$.

Untuk memperoleh gambaran ada tidaknya hubungan antara variabel pemakaian kontrasepsi suntik dengan peningkatan berat badan maka dibuat tabulasi silang (cross Table) terhadap variabel tersebut dengan pembuktian hipotesa dengan menggunakan uji koefisien phi.

Tabel 5.6 Tabel silang antara akseptor KB suntik dengan peningkatan berat badan di BPS Dwenti Krudia. Sumberejo kecamatan lamongan kabupaten lamongan tahun 2015.

\begin{tabular}{|c|c|c|c|c|c|c|}
\hline \multirow{2}{*}{$\begin{array}{c}\text { Kontr } \\
\text { asepsi } \\
\text { suntik }\end{array}$} & \multicolumn{3}{|c|}{ Peningkatan Berat Badan } & \multicolumn{2}{c|}{ Total } \\
\cline { 2 - 7 } & Naik & $\%$ & $\begin{array}{c}\text { Tdk } \\
\text { Naik }\end{array}$ & $\%$ & $\begin{array}{c}\text { Jum } \\
\text { lah }\end{array}$ & $\%$ \\
\hline 1 & 8 & 80.0 & 2 & 20.0 & 10 & 100 \\
bulan & 18 & 100 & 0 & 0 & 18 & 100 \\
3 & 26 & 92,9 & 2 & 7,1 & 28 & 100 \\
bulan \\
Jumla \\
h
\end{tabular}

Sumber: kartu $K B$

Berdasarkan tabel 5.6 dapat diketahui bahwa sebagian besar responden di BPS Dwenti Krudia. Sumberejo Kecamatan Lamongan Kabupaten Lamongan. Akseptor KB suntik 3 bulan terjadi peningkatan berat badan sebanyak 18 akseptor dari $18(100 \%)$ dan didapatkan 8 akseptor dari $10(80,0 \%)$ responden KB suntik 1 bulan terjadi peningkatan berat badan.

Dari hasil statistik uji koefisien korelasi phi ( $\mathrm{r} \varnothing)$ didapatkan value $=0,372$, nilai $\mathrm{T}$ hitung $(3,877)$. 
dan dengan uji SPSS versi 16,0 dengan $\mathrm{p}=0,049$ dimana $<0,05$, maka Ho ditolak yang berarti ada hubungan yang bermakna antara kontrasepsi suntik dengan peningkatan berat badan akseptor.

\section{ANALISA}

Dari data yang sudah ditabulasi kemudian dianalisis menggunakan uji koefisien Phi didapatkan value $=0,372$, nilai $T$ hitung $(3,877)$. dan dengan uji SPSS versi 16,0 dengan $p$ : 0,049 dimana < 0,05, hal ini menunjukkan bahwa $\mathrm{H} 0$ ditolak artinya ada hubungan antara kontrasepsi suntik dengan peningkatan berat badan di BPS Dwenti Krudia. Sumberejo Kecamatan Lamongan Kabupaten Lamongan tahun 2015.

\section{Pemakaian KB Suntik}

Hasil penelitian dilakukan terhadap 28 responden, dari tabel 5.2 dapat diketahui bahwa sebagian besar responden di BPS Dwenti Krudia. Sumberejo Kecamatan Lamongan Kabupaten Lamongan akseptor KB suntik pendidikan terakhirnya SMA sebanyak 15 akseptor dari 28 akseptor KB suntik $(53,6 \%)$ dan sebagian kecil pendidikan terakhirnya PT sebanyak 6 akseptor dari 28 akseptor KB suntik $(21,4 \%)$.

Menurut Stright (2004). Kontrasepsi suntik adalah obat pencegah kehamilan yang pemakaiannya dilakukan dengan jalan menyuntikkan obat tersebut pada wanita subur. Salah satu tujuan utama dari kontrasepsi ini adalah untuk mengembangkan suatu metode kontrasepsi yang berdaya kerja panjang (lama) yang tidak membutuhkan pemakaian setiap hari atau setiap akan bersenggama, tetapi tetap reversibel.

Dari hasil penelitian sebagian besar akseptor KB suntik pendidikan terakhirnya SMA. Berdasarkan hal tersebut ternyata pendidikan bukanlah faktor yang mempengaruhi akseptor dalam pemakaian kontrasepsi yang diinginkan. Seorang yang berpendidikan tinggi belum tentu mengetahui dan memahami semua metode kontrasepsi yang ada. Untuk itu apabila akseptor ingin menggunakan kontrasepsi harus benar-benar mengetahui macammacam kontrasepsi, indikasi dan kontra indikasi kontrasepsi, efek samping dari kontrasepsi yang akan digunakan oleh wanita usia reproduksi.

\section{Peningkatan Berat Badan}

Hasil penelitian dilakukan terhadap 28 responden. Dari tabel 5.2 dapat diketahui bahwa kebanyakan responden di BPS Dwenti Krudia. Sumberejo Kecamatan Lamongan Kabupaten Lamongan. Akseptor KB suntik tidak bekerja sebanyak 18 akseptor dari 28 akseptor KB suntik $(64,3 \%)$.

Berat badan adalah volume tubuh manusia yang terdiri dari cairan tubuh dan jaringan tubuh, yang cara ukurannya menggunakan timbangan berat badan dewasa dengan satuan kilogram. Ukuran ini penting dalam setiap pemeriksaan kesehatan pada setiap kelompok umur yang dapat menggambarkan keadaan kesehatan dan gizi seseorang. (Syamsudin, 1985).

Peningkatan berat badan adalah berubahnya ukuran berat, baik bertambah atau berkurang akibat dari konsumsi makanan yang diubah menjadi lemak dan disimpan di bawah kulit. 
Dari hasil penelitian sebagian besar responden yang mengikuti KB suntik mengalami peningkatan berat badan, karena di dalam KB suntik mengandung hormon estrogen dan progesteron. Di mana kenaikan berat badan merupakan kelainan metabolisme yang paling sering dialami oleh manusia.

\section{Hubungan Antara Kontrasepsi Suntik Dengan Peningkatan Berat Badan Akseptor}

Dari hasil statistik uji

koefisien korelasi phi ( $\mathrm{r} \varnothing)$ didapatkan value $=0,372$, $\mathrm{T}$ hitung $(3,877)$. dan dengan uji SPSS versi 16,0 dengan $\mathrm{p}$ : 0,049 dimana < 0,05, maka Ho ditolak yang berarti ada hubungan yang bermakna antara kontrasepsi suntik dengan peningkatan berat badan akseptor.

Berdasarkan hasil tabulasi silang dari tabel 5.6 Menunjukkan bahwa sebagian besar ibu akseptor KB suntik mengalami peningkatan berat badan setelah pemakaian KB suntik.

$\begin{array}{rll}\text { Hasil } & \text { penelitian ini } & \text { sesuai } \\ \text { dengan } & \text { pendapat } & \\ \text { (Anna }\end{array}$
Glasier:2005) Perubahan kenaikan berat badan ini dapat dipengaruhi oleh berbagai faktor seperti faktor hormonal yang terkandung dalam kontrasepsi suntik yaitu hormon estrogen dan progesteron.

Menurut Rahardja Kirana (2007), berat badan akseptor KB suntik Depo Provera dapat bertambah 1-3 $\mathrm{kg}$ dalam waktu 2 bulan setelah penyuntikan karena pengaruh hormonal, yaitu progesterone. Progesterone dalam alat kontrasepsi tersebut berfungsi untuk mengentalkan lendir serviks dan mengurangi kemampuan rahim untuk menerima sel yang telah dibuahi. Namun hormon ini juga mempermudah perubahan karbohidrat menjadi lemak, sehingga sering kali efek sampingnya adalah penumpukan lemak yang menyebabkan berat badan bertambah. Ditambahkan oleh Hanafi Hartanto (2010) bahwa penyebab pasti pertambahan berat badan tidak jelas, yang jelas telah terjadi pertambahan lemak dalam tubuh. Hipotesa para ahli menyebutkan bahwa DMPA yang terkandung dalam Depo Provera merangsang pusat pengendali nafsu makan di hipotalamus yang menyebabkan akseptor makan lebih banyak daripada biasanya sehingga bertambahnya lemak dalam tubuh. Selain itu, terdapat perbedaan yang signifikan pula antara akseptor KB suntik Depo Provera yang aktif dan yang pasif dengan peningkatan berat badan.

Pada dasarnya perubahan berat badan dipengaruhi oleh beberapa faktor. Secara umum faktor tersebut dapat dibagi atas dua golongan besar yaitu faktor intern dan faktor ekstern (Bindiknakes, 2001:40): faktor intern Adalah faktor yang dapat mempengaruhi berat badan seseorang dan bersumber dari atau pada tubuh itu sendiri. Dalam hal ini terbagi menjadi 4 bagian yaitu: usia, kejiwaan dan hereditas. Sedangkan untuk faktor ekstern Maksudnya adalah semua faktor yang dapat berpengaruh terhadap perubahan berat badan secara langsung dan bersumber dari luar tubuh terbagi menjadi 2 bagian yaitu: makanan dan lingkungan fisik.

\section{Keterbatasan}

Keterbatasan adalah kelemahan atau keterlambatan dalam penelitian. Dalam hal ini peneliti akan melakukan seminimal mungkin 
disebabkan karena hal sebagai berikut:

Pengambilan Data

Sampel yang digunakan jumlahnya terbatas atau sedikit sehingga hasilnya kurang bisa digeneralisikan.

Instrument

Ceklist sebagai alat ukur atau alat pengambilan data dan tidak dilakukan uji validitas terlebih dahulu, sehingga hasilnya kurang bisa valid dan reliabel.

\section{Literatur}

Buku yang digunakan acuan dalam penelitian ini tidak banyak sehingga penelitian ini masih memerlukan penyempurnaan.

\section{KESIMPULAN}

Berdasarkan hasil penelitian dan pembahasan melalui hubunga kontrasepsi suntik dengan peningkatan berat badan akseptor di BPS Dwenti Krudia,Amd.Keb. desa sumberejo kecamatan Lamongan Kabupaten Lamongan, dapat dirumuskan simpulan sebagai berikut:

1. Sebagian besar akseptor KB suntik mengikuti KB suntik 1 bulan dan 3 bulan

2. Sebagian besar akseptor KB suntik mengikuti KB suntik 1 bulan dan 3 bulan kebanyakan mengalami peningkatan berat badan

3. Terdapat hubungan KB suntik dengan peningkatan berat badan pada akseptor KB suntik di BPS. Dwenti Krudia desa Sumberejo Lamongan.

\section{Saran}

1. Bagi responden harus mengetahui KB yang cocok dan mengetahui semua efek samping dari jenis KB yang akan dipakai, terutama KB suntik yang sering digunakan oleh masyarakat.

2. Bagi institusi, harus memberikan banyak buku atau literatur agar dapat memberikan kajian ilmu khususnya dalam bidang kepustakaan.

3. Bagi lahan praktek, harus lebih baik lagi dalam meningkatkan pelayanan kesehatan.

\section{DAFTAR PUSTAKA}

Departemen Kesehatan RI. 2001. Buku Pedoman Petugas Fasilitas Pelayanan keluarga Berencana. Jakarta: Bina Kesehatan Masyarakat.

Glasier, Anna. 2005. Keluarga Berencana dan Kesehatan Reproduksi. Jakarta: EGC.

Hartanto, Hanafi. 2004. Keluarga Berencana dan kontrasepsi. Jakarta: Puspa Sinar Harapan.

Hidayat, Alimul Aziz, (2010). Metode Penelitian Kebidanan dan Teknik Analisis Data. Jakarta. Salemba Medika.

Kuntoro, Haji. 2007. Metode Statistik. Surabaya, Pustaka Melati.

Manuaba, IGB, (1998). Ilmu Kebidanan, Penyakit kandungan, dan KB. EGC. Jakarta

Mochtar, R. (1998). Sinopsis Obstetri, Obstetri Fisiologi, Obstetri Patologi, bagian 1. EGC, Jakarta.

Nursalam, (2008). Konsep dan Penerapan Metodologi Penelitian Ilmu Keperawatan. Salemba Medika. Jakarta.

Nursalam dan Siti Pariani (2001). Pendekatan Praktis dan 
Metodologi Riset Keperawatan. Sagung Seto. Jakarta.

Prawirihardjo, W, (1999). Ilmu Kebidanan, Jakarta. YBP-SP.

Prastowo, Andi. 2015. Memahami Metode-Metode Penelitian. Jogjakarta: Ar-Ruz Media.

Purnomo, W. (2002). Metodologi Penelitian, Hand out dan Bahan Kuliah.

Saifuddin, AB, dkk. (2003). Buku panduan Praktis Pelayanan Kontrasepsi, Jakarta. YBP-SP.

Soekidjo, Notoatmodjo. (2005), Metodologi Penelitian Kesehatan. Rineka Cipta. Jakarta.

Suharsimi, Arikunto (1998).

Prosedur Penelitian Suatu Pendekatan Praktek. Jakarta. Rineka Cipta

Verralls, 2008. Anatomi dan Fisiologi Terapan dalam Kebidanan Edisi ke 3. Jakarta: EGC 